\title{
BENEFITS AND CHALLENGES OF MAGUGA DAM RESETTLETMENT SCHEME TO DISPLACED PEOPLE IN HHOHHO REGION OF ESWATINI
}

\author{
Jibowo, A. A. ${ }^{1}$ and Mncina, M. ${ }^{2}$ \\ Correspondence author: A. A. Jibowo. Email: aajibowo@ yahoo.com
}

\begin{abstract}
Land development features land redistribution, construction of dams, land resettlement of displaced persons, as well as improvement of land fertility status through measures such as planting of grasses, herbs and trees. These features often result in benefits and encounter challenges. The purpose of this study was to identify the benefits derived from, and challenges encountered in the Maguga Dam resettlement scheme in Hhohho Region of Eswatini. Out of the 66 family members who were relocated, 58 took part in the study by providing data through interviews conducted using an interview schedule. A six-point Likert-type scale was used to measure the benefits, challenges and attitudes of the people to the new place of settlement. The benefits derived from the resettlement scheme included assistance in building new houses (100\%) and provision of fertile land (100\%). Over 90\% benefitted from increased visits by extension agents, and formation of associations. The majority of the respondents (86.2\%) indicated that compensation was adequate. Some challenges faced by most of the displaced people were poor water supply (91.4\%), inadequate crop storage facilities (96.6\%), inadequate farm inputs (94.8\%), theft (98.3\%), crop pests (96.6\%), and transport facilities (100\%). The majority (80.54\%) had positive attitudes towards the new place of settlement. Some socio-economic characteristics had moderate and low associations with benefits derived from the resettlement scheme. In conclusion, many benefits and few challenges were experienced in the resettlement scheme. It was recommended that extension agents should intensify their contact with farmers to remove farming challenges such as inadequate farm inputs, storage facilities and access to markets.
\end{abstract}

Keywords: Attitude, Benefits, Challenges, Dam, Resettlement scheme

\section{INTRODUCTION}

\subsection{Background situation}

Swaziland was renamed Eswatini in 2018. The development programmes before the re-naming of the country continued. One of the projects was the establishment of the Maguga Dam which involved displacement of 124 homesteads from the Ekuvinjelweni Traditional Authority in Hhohho Region (Komati Basin Water Authority (KOBWA), 2002). There were three resettlement options, namely (i) resettlement to a designated host area and an in-kind compensation; (ii) local relocation within the displaced homestead's chiefdom and in-kind compensation; and (iii) free choice resettlement to an area identified by the displaced homestead and cash compensation. A land area located approximately $20 \mathrm{~km}$ downstream of

\footnotetext{
${ }^{1}$ Professor, Department of Agricultural Education and Extension, University of Eswatini, Luyengo, Eswatini, Email: aajibowo@yahoo.com

${ }^{2}$ Student, Department of Agricultural Education and Extension, University of Eswatini, Luyengo, Eswatini, Email: aajibowo@yahoo.com
} 
the dam wall on the southern bank of the Komati River was identified for resettlement after an investigation was carried out for its suitability. Representatives of the proposed re-settlers visited the site and agreed that it was suitable for resettlement. Their major consideration was that the site had adequate and suitable land area for crop farming and rearing of livestock (KOBWA, 1996).

\subsection{Benefits and challenges of constructed dams}

Benefits that are derived by the local communities as a result of dam construction include increased generation of funds from irrigated land and tourism, increased infrastructural development which accompanies the project such as road and house construction, water supply and sanitation, provision of health clinics and sports facilities, and increased job skills imparted through the project (Government of Swaziland (GoS), 2008). Other benefits include increased income, electricity supply, fuel wood and timber, and fodder for livestock. The productivity of the land will increase significantly; water supply will also increase for irrigation, industries, human and animal consumption (KOBWA, 2002).

Construction of dams also results in a number of challenges. People who have settled in a place for decades are forced to move away. In addition, the shock of resettlement takes some time to disappear. Resources which have been accumulated over the years are destroyed or disrupted. Houses and farmlands are flooded. Permanent crops such as mangos, and perennial crops such as bananas are damaged. The land with grasses is no more suitable for livestock grazing because grasses have been submerged by water. According to Manyatsi (2005), dam issues are not confined to design, construction and operation alone, they also include social, environmental and political choices with consequent benefits and challenges to the people.

Since the construction of the Maguga Dam, no systematic study was identified by the authors on the benefits derived and challenges encountered by the resettled people displaced from the dam area. This study was conducted to fill this gap.

\subsection{Objectives of the study}

The objectives of the study were to:

1. Identify the benefits derived from the Maguga Dam resettlement scheme;

2. Describe the challenges encountered by the displaced people as a result of resettlement;

3. Identify the problems of socio-economic adjustment encountered by the resettled people; and

4. Assess the attitude of respondents to their new environment where they were resettled.

\subsection{Hypotheses of the study}

Null Hypothesis: There is no association between personal and socio-economic characteristics of resettled people and benefits derived from the resettlement scheme.

Alternative Hypothesis: There is an association between personal and socio-economic characteristics of resettled people and benefits derived from the resettlement scheme. 


\section{METHODOLOGY}

\subsection{Population and sample}

The target population consists of the household heads who were resettled as a result of displacement from their settlements as a result of Maguga Dam construction. Purposive sampling was used to select the respondents for this study. Out of 124 households displaced by the dam construction, 66 were relocated to the designated host area. All 58 heads of households and their representatives who were available in the host community during the period of the study were included in the study. The sample included 17 respondents from Ngonini, 17 from Emtototshe, 15 from Ekwakheni, and nine from Emganwini.

\subsection{Instrumentation}

An interview schedule was constructed to measure the different objectives of the study. A 6point Likert-type scale was used to measure the variables. Benefits derived from the resettlement scheme was measured by the levels of agreement as $1=$ Strongly Disagree, $2=$ Disagree, $3=$ Slightly Disagree, $4=$ Slightly Agree, $5=$ Agree, and $6=$ Strongly Agree to each benefit listed. Similarly, respondents were asked to indicate their levels of agreement to challenges and socio-economic adjustment problems faced as a result of resettlement from the list of challenges and problems provided in the interview schedule. Attitudes of respondents to their new environments were also measured by their levels of agreement to positive attitude statements towards the places in which they were resettled.

\subsection{Reliability, validity and ethical considerations}

Reliability of the instrument was established by asking 30 farmers who experienced resettlement after displacement by another dam construction to complete the interview schedule. Test-retest method (Van Dalen \& Meyer, 1966) was used to calculate the reliability coefficient of 0.75 , which indicated that the instrument was reliable. Content validity of the instrument was determined by asking two lecturers from the University of Eswatini who were familiar with the problem of the study, as well as an Extension Agent who was familiar with the problem, to complete the interview schedule and suggest amendments. Their suggested amendments were incorporated into the instrument. Face validity was ensured by using an appropriate cover of one of the resettled communities for the questionnaire. Unambiguous and understandable expressions were also used. Ethical consideration was facilitated by not requiring respondents to disclose their identities. According to Creswell (2009), researchers need to protect their research participants, earn their trust by ensuring that the information will not be used against the participants, promote integrity, and guide against misconduct.

\subsection{Data collection and data analysis}

The researcher and a trained enumerator collected the data by interviewing 58 resettled respondents through the use of the valid and reliable interview schedule to collect quantitative data. Qualitative data were also collected by writing down observations and relevant information not requested in the interview schedule in field notebooks. Data analysis was carried out by using the Statistical Package for Social Sciences, version 20. Means, standard deviations, frequencies and percentages were generated to describe the data. Correlation analysis was carried out to test the hypotheses. 


\section{RESULTS AND DISCUSSION}

This section presents the analysis, description and discussion of data for the study. Specifically, it covers benefits derived from the resettlement scheme, challenges and adjustment problems encountered as a result of the resettlement, attitude towards the new places to which they were resettled, and association between personal and socio-economic characteristics and economic benefits derived from the resettlement scheme.

\subsection{Benefits derived from the resettlement scheme}

Figure 1 indicates that most of the respondents derived many benefits from the resettlement scheme. All the respondents $(100 \%)$ agreed that assistance on new house building, provision of fertile land, and provision of electricity were benefits. Over $90 \%$ agreed that formation of associations and increased visits by extension agents were benefits. Other benefits derived by the majority of the respondents included improvement in education, assistance in citrus farms (60\%), employment creation, and easy access to water supply. Over $90 \%$ disagreed that landless people were allocated lands, and receiving assistance in establishing new sugarcane farms. Over $70 \%$ did not agree on the provision of roads. Few respondents disagreed that the other benefits were derived.

\section{Benefits Derived from the Resettlement Scheme}

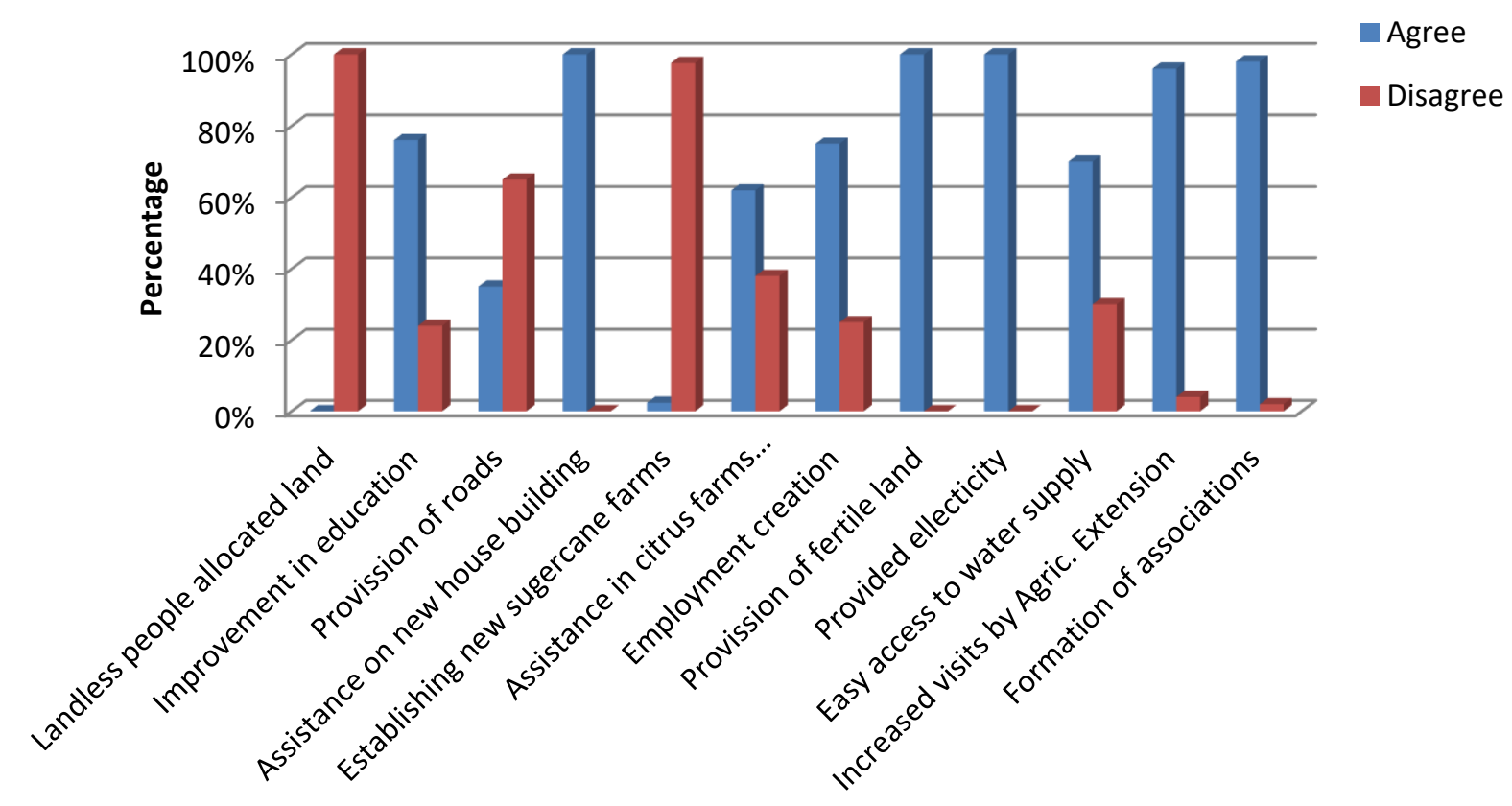

- Agree

Disagree

Figure 1: Benefits derived from the Maguga Dam resettlement scheme

\subsection{Adequacy of compensation}

Figure 2 shows that the majority of respondents (86.2\%) indicated that the compensations paid for improvements on the land from which respondents were displaced such as houses and crops were adequate. A few of the respondents $(13.8 \%)$ indicated that the compensations they 
received were not adequate. The respondents were therefore adequately compensated for the losses they sustained as a result of the resettlement scheme.

\section{Compensation}

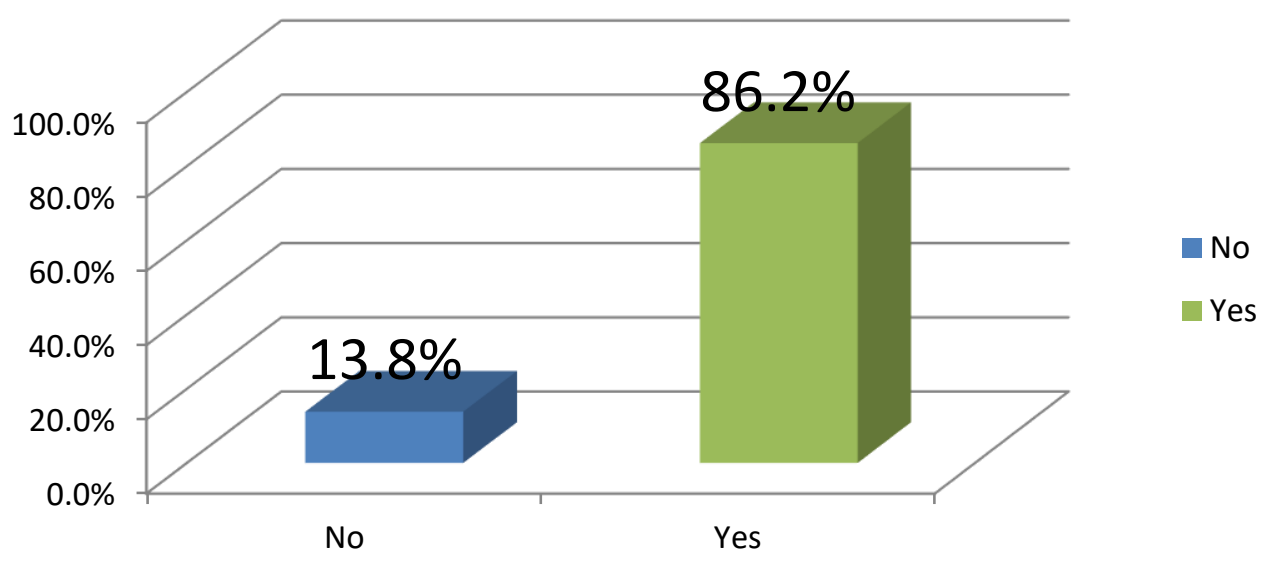

Figure 2: Adequacy of compensations received by respondents

\subsection{Problems of socio-economic adjustment encountered}

Data in Table 1 indicates that the majority of the respondents did not encounter problems of socio-economic adjustment in their new places of resettlement. The only problem mentioned by $50 \%$ of the respondents was far distance to school. The majority of the respondents did not encounter problems with visiting family members $(94.8 \%)$, distance from Rural Development Area offices $(75.9 \%)$, availability of recreational facilities $(75.9 \%)$, visiting neighbours $(74.1 \%)$, membership of social clubs $(61.3 \%)$, visiting friends $(60.3 \%)$, and nearness to church $(55.2 \%)$.

Table 1: Problems encountered in adjusting to the new environment $(n=58)$

\begin{tabular}{|l|l|l|}
\hline Problems & Yes $(\boldsymbol{\%})$ & No $(\boldsymbol{\%})$ \\
\hline Visiting friends & 39.7 & 60.3 \\
\hline Visiting family members & 5.2 & 94.8 \\
\hline Visiting neighbours & 25.9 & 74.1 \\
\hline Nearness to church & 44.8 & 55.2 \\
\hline Nearness to school & 50.0 & 50.0 \\
\hline Nearness to RDA & 24.1 & 75.9 \\
\hline Availability of recreational facilities & 24.1 & 75.9 \\
\hline Membership of social clubs & 39.7 & 61.3 \\
\hline
\end{tabular}

\subsection{Challenges encountered by the displaced people as a result of resettlement}

Data in Table 2 shows that the majority of the respondents agreed that they encountered five (29.4\%) out of the 16 challenges indicated. Most of the respondents $(70.6 \%)$ did not encounter many of the challenges. The challenges encountered were increased morbidity (100\%), theft (98.3\%), pest infestation of crops (96.6\%), shortage of storage facilities (96.6\%), and shortage of farm inputs like seeds $(94.8 \%)$. It was observed that the challenges faced by the respondents 
in the places of resettlement were few. It is necessary to assist the respondents in removing the challenges by providing adequate medical facilities, security of lives and properties, controlling crop pests, providing needed farm inputs at subsidised rates, and storage facilities for farm products.

Table 2: Challenges faced by resettled people $(n=58)$

\begin{tabular}{|l|l|l|}
\hline Statement & Agree (\%) & Disagree (\%) \\
\hline Inadequate farm land & 25.9 & 74.1 \\
\hline Infertile soil & 30.2 & 69.8 \\
\hline Cultivation & 22.4 & 77.6 \\
\hline Storage facility & 96.6 & 3.4 \\
\hline Inputs like seeds & 94.8 & 5.2 \\
\hline Bad climatic condition & 0 & 100 \\
\hline Theft & 98.3 & 1.7 \\
\hline Jealousy from other people & 41.3 & 58.7 \\
\hline Natural disaster & 1.7 & 98.3 \\
\hline Pests & 96.6 & 3.4 \\
\hline Disease outbreaks & 27.6 & 72.4 \\
\hline Storage losses & 0 & 100 \\
\hline Loss of livelihood & 31 & 69 \\
\hline Increased morbidity & 100 & 0 \\
\hline Access to market & 35 & 65 \\
\hline Transport to town & 0 & 100 \\
\hline Mean & $\mathbf{4 3 . 8}$ & $\mathbf{5 6 . 2}$ \\
\hline
\end{tabular}

\subsection{Attitudes of respondents towards the new environment into which they were resettled}

Data in Table 3 shows that the majority of the respondents had positive attitudes towards the resettled environment. This is because an average of $80.5 \%$ agreed to the 10 positive attitude statements to each of which they were required to indicate their level of agreement. Only some respondents with a mean percentage of $19.5 \%$ who disagreed, had negative attitudes. The notable positive attitudes were reflected in agreement by all (100\%) respondents to three of the statements including "life is relatively pleasant", "farmers are regularly visited by change agents", and "the settlement is a good place to live in". The only statement to which the majority of respondents $(56.9 \%)$ disagreed was "people trust one another". If most of the people do not trust one another, yet it is easy to get along with other settlers (69\%), it may be because it does not take long to get over feeling bad (72.4\%). Regardless of the preceding explanation, it is necessary to find out causes of lack of trust among the people, and introduce measures to bring about improvement in trust. 
Table 3: Attitudes of respondents towards the resettled area $(n=58)$

\begin{tabular}{|l|l|l|}
\hline Statements & Agree (\%) & Disagree (\%) \\
\hline Any man prepared to work hard can get a good living & 98.3 & 1.7 \\
\hline Times are getting better & 75.9 & 24.1 \\
\hline Life is relatively pleasant & 100 & 0 \\
\hline People trust one another & 43.1 & 56.9 \\
\hline It is easy to get along with other settlers & 69 & 31 \\
\hline Farmers are visited by change agents & 100 & 0.0 \\
\hline Does not take long to get over feeling bad & 72.4 & 27.6 \\
\hline I prefer staying in the resettlement area & 86 & 14 \\
\hline Life is relatively safe & 60.7 & 39.7 \\
\hline The settlement is a good place to live in & 100 & 0. \\
\hline
\end{tabular}

\subsection{Demographic characteristics of respondents}

Data in Table 4 portrays the demographic characteristics of respondents.

Headship of households: The majority of respondents (83\%) were heads of households; few $(17 \%)$ were not heads of households. This was because house-heads were deliberately selected for the study. Those who were not heads were included where the heads were not available during the entire period of the study.

Sex: About three quarters of the respondents $(74 \%)$ were male, while $26 \%$ were female. This result is consistent with the universal culture that most households are headed by males.

Age: The majority of participants (55.2\%) were between 30 and 49 years of age, with a mean age of 43.7 years. The resettled people were therefore middle-aged and strong enough to take an active part in agricultural and other development programmes in the areas.

Marital status: About three quarters of the respondents $(75.9 \%)$ were married, $10.3 \%$ were single, and the remaining few were widowed (8.6\%), divorced $(3.5 \%)$ and separated $(1.7 \%)$. It should be noted that the occurrences of divorce and separation were very few in rural areas, hence the respondents still observe the culture of marital stability. This finding is contrary to the impression that marital stability is disappearing in Eswatini. It is necessary to find out percentages of divorce and separation in urban marriages.

Highest formal education: Most of the respondents (93.1\%) had formal education; only $6.9 \%$ had no formal education. Out of those who had formal education, 37.9\% had high school education, $19 \%$ had secondary school education, and $12.1 \%$ had vocational training. It was gratifying that $24.1 \%$ had tertiary education. The respondents were therefore perceived to be well educated.

Occupation: About a quarter of the respondents (25.9\%) were full-time farmers. Furthermore, $8.6 \%$ were part-time farmers while $20.7 \%$ were farm workers. The remaining respondents $(44.8 \%)$ were made up of civil servants $(32.8 \%)$ and those who were employed in the private sector $(12 \%)$. 
Vol. 47 No. 4, 2019: 18 - 28

http://dx.doi.org/10.17159/2413-3221/2019/v47n4a523

Table 4: Demographic characteristics of respondents $(n=58)$

\begin{tabular}{|c|c|c|}
\hline Headship of households & Frequency & Percent $(\%)$ \\
\hline Head of household & 48 & 83 \\
\hline Not head of household & 10 & 17 \\
\hline Total & 58 & 100 \\
\hline Sex & Frequency & Percent (\%) \\
\hline Male & 43 & 74 \\
\hline Female & 15 & 26 \\
\hline Total & 58 & 100 \\
\hline Age (Years) & Frequency & Percent (\%) \\
\hline $20-29$ & 8 & 13.8 \\
\hline $30-39$ & 12 & 20.7 \\
\hline $40-49$ & 20 & 34.5 \\
\hline $50-59$ & 10 & 17.2 \\
\hline Above 60 & 8 & 13.8 \\
\hline \multicolumn{3}{|l|}{ Mean $=43.2$ years } \\
\hline Total & 58 & 100 \\
\hline Marital status & Frequency & Percent (\%) \\
\hline Single & 6 & 10.3 \\
\hline Married & 44 & 75.9 \\
\hline Divorced & 2 & 3.5 \\
\hline Widowed & 5 & 8.6 \\
\hline Separated & 1 & 7.1 \\
\hline Total & 58 & 100 \\
\hline Highest education & Frequency & Percent $(\%)$ \\
\hline No formal education & 4 & 6.9 \\
\hline Vocational education & 7 & 12.1 \\
\hline Secondary school & 11 & 19 \\
\hline High school & 22 & 37.9 \\
\hline Tertiary education & 14 & 24.1 \\
\hline Total & 58 & 100 \\
\hline Occupational status & Frequency & Percent (\%) \\
\hline Full-time farmer & 15 & 25.9 \\
\hline Farm worker & 12 & 20.7 \\
\hline Part-time farmer & 5 & 8.6 \\
\hline Private sector & 7 & 12 \\
\hline Civil servant & 19 & 32.8 \\
\hline Total & 58 & 100 \\
\hline
\end{tabular}




\subsection{Testing of hypotheses}

The null hypothesis that there was no association between demographic characteristics and benefits derived from the resettlement scheme was tested against the alternative hypothesis that there was an association. Table 5 contains the Davis (1992) scale of descriptors which was used to interpret the findings of the correlation analysis.

Table 5: Davis scale of descriptors

\begin{tabular}{|l|l|}
\hline Correlation Coefficient (r) & Description \\
\hline 1.0 & Perfect association \\
\hline 0.70 to 0.99 & Very high association \\
\hline 0.50 to 0.69 & Substantial association \\
\hline 0.30 to 0.49 & Moderate association \\
\hline 0.10 to 0.29 & Low association \\
\hline 0.01 to 0.09 & Negligible association \\
\hline
\end{tabular}

Data in Table 6 shows a moderately positive association $(\mathrm{r}=0.341)$ between farming experience in years and benefits derived from the resettlement scheme. This means that the greater the years of farming experience of respondents, the more the benefits derived from the resettlement scheme. This is consistent with expectation since respondents with many years in farming must have acquired enough resources and experiences to apply in using the resources provided through the scheme. However, the association between sex and benefits shows a moderately negative association $(\mathrm{r}=-0.384)$. This means that males derived less benefits from the scheme than females. This is contrary to expectation as there were more males in the scheme than females. It is possible that females were more efficient users of the benefits. A future study should provide concrete reasons for this finding. The associations between the other demographic characteristics studied and benefits were low and largely negligible.

Table 6: Inter-correlations among selected demographic characteristics and benefits derived from the scheme $(n=58)$

\begin{tabular}{|l|l|l|l|l|l|l|l|l|l|l|}
\hline & $\mathrm{Y}$ & $\mathrm{X}^{1}$ & $\mathrm{X}^{2}$ & $\mathrm{X}^{3}$ & $\mathrm{X}^{4}$ & $\mathrm{X}^{5}$ & $\mathrm{X}^{6}$ & $\mathrm{X}^{7}$ & $\mathrm{X}^{8}$ & $\mathrm{X}^{9}$ \\
\hline $\mathbf{Y}$ & 1.00 & & & & & & & & & \\
\hline $\mathbf{X}^{\mathbf{1}}$ & -.103 & 1.00 & & & & & & & & \\
\hline $\mathbf{X}^{\mathbf{2}}$ &.- .384 & -.311 & 1.00 & & & & & & & \\
\hline $\mathbf{X}^{\mathbf{3}}$ & -.199 & .137 & -.159 & 1.00 & & & & & & \\
\hline $\mathbf{X}^{\mathbf{4}}$ & -.092 & -.236 & .256 & -.036 & 1.00 & & & & & \\
\hline $\mathbf{X}^{\mathbf{5}}$ & .082 & -.053 & .006 & .145 & -.084 & 1.00 & & & & \\
\hline $\mathbf{X}^{\mathbf{6}}$ & -.031 & .141 & -.073 & -.264 & .128 & -.307 & 1.00 & & & \\
\hline $\mathbf{X}^{\mathbf{7}}$ & -.047 & .287 & .119 & -.120 & -.099 & -.120 & .117 & 1.00 & & \\
\hline $\mathbf{X}^{\mathbf{8}}$ & .341 & -.149 & .413 & -.345 & .123 & -.016 & -.203 & .359 & 1.00 & \\
\hline $\mathbf{X}^{\mathbf{9}}$ & .006 & -.068 & -.032 & -.015 & .217 & .029 & .197 & .238 & .133 & 1.00 \\
\hline
\end{tabular}

Dependent variable: $\mathrm{Y}=$ Allocation of land, improvement in educational facilities, provision of external markets, provision of road system, construction of new house, establishment of sugarcane farms, establishment of citrus farms, provision of fertile farming land, construction of modern houses, provision of electricity, access to water supply, increased visits by officers, and formation of associations. (Nominal: $1=$ Strongly Disagree $(S D), 2=$ Disagree $(D), 3=$ Slightly Disagree $(S L D), 4=$ Slightly Agree $(S L A), 5=$ Agree $(A), 6=$ Strongly Agree $(S A)$ ). 
Independent variable: $x^{1}=$ Household headship (Nominal: 0 head, $1=$ not head); $x^{2}=$ Gender (Nominal: $0=$ female, $1=$ male); $\mathrm{x}^{3}=$ Age (Interval: $1=20-29$ years, $2=30-39$ years, $3=40$ 49 years, $4=50-59$ years, $5=60$ years and above); $x^{4}=$ Annual income (Ordinal: $1=10000$ $19000,2=20000-29000,3=30000-39000,4=40000-49000,5=50000-59000,6=60$ 000 and above); $x^{5}=$ Marital status (Nominal: $1=$ Single, $2=$ Married, $3=$ Divorced, $4=$ Widowed, $5=$ Separated); $\mathrm{x}^{6}=$ Level of education (Ordinal: $1=$ No formal schooling, $2=$ Vocational, $3=$ Primary, $4=$ Junior certificate, $5=$ O'level, $6=$ Tertiary); $x^{7}=$ Occupational status (Nominal: 1 = Full-time farmer, $2=$ Part-time farmer, $3=$ Farm worker, $4=$ Private sector employee, $5=$ Civil servant); $\mathrm{x}^{8}=$ Farming experience (Nominal); $\mathrm{x}^{9}=$ Household size (Nominal).

\section{CONCLUSIONS}

Based on the objectives and findings of the study, the following conclusions were made:

- Resettled people derived many benefits from the resettlement scheme. These included assistance on new house building, provision of fertile land, provision of electricity, increased visits by extension agents and formation of development associations. Compensations received for the resources lost as a result of the dam construction were adequate.

- Resettled people encountered many challenges in their new settlement. These challenges included increased morbidity (death), theft, pest infestation, inadequate storage facilities, shortage of inputs like seeds, and poor water supply.

- Far distance of school to the resettled area was the only problem of socio-economic adjustment experienced by the respondents.

- Resettled people had positive attitudes towards their new environment. They agreed that the new settlement is a good place to live in. Any person who is prepared to work hard can get a good living in the new area, thus they preferred staying in the resettled area. However, they did not trust one another.

- The majority of the resettled respondents were heads of households, males aged 30-49 years, married, with high school and tertiary education, engaged in civil service and farming.

- Adequate compensations had been received by the resettled people for properties lost as a result of the resettlement.

- A moderately positive association was obtained between farming experience in years and benefits derived from the resettlement scheme. Hence, as the years of farming experience of the respondents increased, the benefits they derived from the resettlement scheme increased. Furthermore, sex and benefits showed a moderately negative association. The associations between the other demographic characteristics studied and benefits were low and largely negligible.

\section{RECOMMENDATIONS}

The following recommendations can be put forward:

- Management of the resettlement scheme should focus on sustainability and improvement of the many benefits derived from the resettlement scheme by the resettled people including increased education, housing, employment creation, visits by agricultural extension agents, and provision of electricity.

- Agricultural extension should assist farmers to benefit more from establishment of sugarcane and citrus farms. Famers should be assisted to have adequate storage facilities, 
farm inputs like improved seeds and fertilizers. They should also be assisted to control crops and livestock pests.

- Resettled people should be assisted to have improved security of life and properties as well as farm resources. They should have improved access to social services like medical facilities and schools in their settlement area.

- Programmes should be put in place in the resettled areas to increase trust among the people. This can be through improved security, formation of associations that should meet regularly and other means of increased positive social and economic interactions.

\section{REFERENCES}

CRESWELL, J.W., 2009. Research design: Qualitative, quantitative and mixed methods approaches. $3^{\text {rd }}$ ed. Thousand Oaks, C.A: Sage.

DAVIS, J.A., 1992. Elementary survey analysis. Englewood Cliffs, N.J: Prentice-Hall.

GOVERNMENT OF SWAZILAND (GoS), 2008. Country strategy paper and national indicative programme. Mbabane, Swaziland.

MANYATSI, A.M., 2005. Smallholder irrigated agriculture and poverty alleviation in Swaziland. Paper presented to WAFSA/Waternet/GWPSA Symposium. Ezulwini, Swaziland.

KOMATI BASIN WATER AUTHORITY (KOBWA), 1996. Resettlement and compensation policy. Mbabane, Swaziland.

KOMATI BASIN WATER AUTHORITY (KOBWA), 2002. Comprehensive Mitigation Plan (CMP). Report No. 437/2492/2/f. Mbabane, Swaziland.

VAN DALEN, D.B. \& MEYER, W.J., 1966. Understanding educational research. An Introduction. New York: McGraw-Hill Book Company. 
